Acta Universitatis Wratislaviensis • No 3869

Literatura i Kultura Popularna XXIV, Wrocław 2018

DOI: $10.19195 / 0867-7441.24 .4$

\author{
Kamila Żyto \\ ORCID: 0000-0003-2822-8341 \\ University of Łódź
}

\title{
Detours of absurdity: Coen brothers' Fargo in the noir melting pot of genre patterns
}

Keywords: film noir, film history, film genres, cinema of Coen brothers

Słowa kluczowe: film noir, historia filmu, gatunki filmowe, kino braci Coen

The long-lasting debate over whether film noir should be seen as a genre, a cycle or a tendency in the history of cinema remains unsettled. No definitive solution has been found, nor any consensus reached, owing to the fact that the film noir phenomenon is particularly complex and convoluted. Much of the debate revolves around questions of approach and genre. But many movies, both those released in the 1940s and 1950s (the classical period) and those released in the following decades (the neo-noir, or postclassical, period), do not obviously fit any genre pattern or other ordering scheme. The diversity among films that are now unquestionably classified as noir, provokes controversy and raises numerous questions. What does Sunset Boulevard (dir. Billy Wilder, 1950) have in common with The Killers (dir. Robert Siodmak, 1946)? The first one is simultaneously a crime story, melodrama and horror. The second one is, without a doubt, a gangster movie. Do all noir films really constitute a single genre? I will leave this question unanswered, as to support any of the various opinions about the generic identity of film noir is not the main aim of this paper. ${ }^{1}$

From my perspective, there is little utility in joining this on-going debate, which has reached a standstill some time ago. Therefore, I will make no attempt to prove that either film noir is one of popular culture's most recognizable genres, or that it is a historically restricted and determined tendency. Rather, film noir, at its core, is

\footnotetext{
${ }^{1}$ Magdalena Kempna-Pieniążek's monograph on neo-noir cinema identifies nine different approaches to the problem of defining noir. See: M. Kempna-Pieniążek, Neo-noir: Ciemne zwierciadło czasów kryzysu, Katowice 2015, pp. 20-21.
} 
a transgeneric, transnational and transperiodic idea $^{2}$ that has not established fixed, restricted or unchangeable practices (at the level of genre, style or plot patterns) and as a result has not turned into convention. If there is a noir generic convention, it exists rather in viewers' notions or the simplifications that critics are prone to make when applying synthetic reasoning to the material at hand. As a result, noir films are a regularly reappearing phenomenon that has remained influential for the last seven decades and continues to attract the attention of audience, critics and scholars. In this article, I will address the Coen brothers' Oscar-winning Fargo (1996) as a case study whose purpose is to show how noir continues to have vitality, although a vitality which has nothing to do with its constitution as a separate genre, but rather with its constant, subversive treatment of the rules of various genres. ${ }^{3}$ But the point of this article is also to demonstrate how far the movie can get away from what we consider to be "noirish" (not only in terms of genre conventions but also visual style, plot patterns, etc.), and at the same time remain dark at heart, and thus fully and undeniably reflect a noir sensibility. I shall also identify strategies used by the Coen brothers when operating among various film genres. Geoff King has outlined the various ways in which New Hollywood deals with generic rules, through shifting, deconstruction, inflation, and reconstruction, as well as bending, blending, blurring. Most can be found in Fargo, and the movie also features other techniques, such as reversing or reducing. It becomes a melting pot of easily-recognizable genres, where well-known and established patterns are changed, subverted, reconstructed or restructured. ${ }^{4}$

\section{The boiling melting pot of noir genres}

At the outset, and despite my thesis stated above, it is important to recognize that certain genres are more often used by film noir. These genres may be more conducive to expressing noir attitudes, values, worldviews and a philosophy grounded in existentialism and psychoanalysis. Although noir as an idea is flexible as to genre (and therefore theme and emotional tone), ${ }^{5}$ the tendencies are

${ }^{2}$ In this respect I support the opinion of James Naremore, who states that "film noir belongs to the history of ideas as much as to the history of cinema; in other words, it has less to do with a group of artifacts than with a discourse - a loose, evolving system of arguments and readings that helps to shape commercial strategies and aesthetic ideologies. [...] film noir is both an important cinematic legacy and idea we have projected onto the past" - J. Naremore, More Than Night: Film Noir in its Contexts, Berkeley-Los Angeles-London 2008, p. 11.

${ }^{3}$ In Chapter 3, Section 2 of Film Noir and the Work of the Coen Brothers I analyze the Oscar-winning Fargo in more detail, however in a different context and from a different perspective. I try to prove that the movie is noir deep down at heart, mainly by referring to the docu-noir tradition rather than by examining its generic complexity. See: K. Żyto, Film noir i kino braci Coen, Łódź 2017, pp. 217-265.

${ }^{4}$ G. King, New Hollywood Cinema, New York 2001, pp. 116-147.

${ }^{5}$ It is worth reminding that film genres are defined either by dominating emotional tone (melodramas, comedies or horrors) or by thematic scope (westerns, detective stories). 
nevertheless significant. These tendencies were recognized by scholars researching and attempting to describe film noir. Of course it was mainly visual style that became the hallmark of noir cinema, but early on Raymond Borde and Étienne Chaumeton, in their classic book on film noir (Panorama du film noir américain, published in France in 1955), described it as a synthesis of three different genres that, in those times, had become so distinct that individual film studios each specialized only in one of them. Thus, Warner Bros. focused on gangster movies, Universal on horror films, and MGM and Fox preferred classical, deductive detective stories. ${ }^{6}$ Film noir in Borde and Chaumeton's opinion was a kind of cinema born out of these three genres, but deriving only certain elements from each. Detective stories gave to film noir the power of observation and atmosphere of alienation, horror provided it with a mise-en-scène steeped in disgust and terror, and gangster movies offered a rebellious, armed antihero. ${ }^{7}$

Film noir owes much more to gangster movies and detective stories than that (borrowing, for example, themes, type of protagonist), and naturally stays in touch with the spirit of horror cinema but also — in my opinion — flirts with melodrama, crime story, police drama, thrillers, mystery films and others genres or subgenres. Alicja Helman claims that: "The influences of film noir were highly significant and extensive and spread over different genres, from social drama to costume melodrama". ${ }^{8}$ Additionally, it is worth bearing in mind that noir, when it emerged in classical Hollywood cinema at the beginning of the 1940s, modified the convention of many already well established genres, such as gangster movies. Those genres that were mainly overtaken by noir (crime and detective stories, gangster films) evolved more drastically. They became more pessimistic, even nihilistic in tone, and the world they depicted sunk in turmoil; neither rules nor better prospects or moral values could be found on the horizon. The social diagnosis presented in these movies indicated that, as Alicja Helman observed, "civilization took a wrong turn and the authors would ask about the possibility of living a life which could be meaningful in some ways". 9

Fargo clearly refers to and uses the conventions of the three genres mentioned by Borde and Chaumeton and often shifts from one to the other. Additionally, the Coen brothers' movie also contains elements of police drama, family drama and even slapstick comedy. But it is essential to stress that even when using the most canonic devices of film noir (such as the detective story or the gangster film), the Coens are highly subversive. They blend, bend and blur generic bound-

${ }^{6}$ P. Kerr, "Out of what past? Notes on the B 'film noir"”, [in:] Film Noir Reader, eds. A. Silver, J. Ursini, New York 2000, p. 103.

${ }^{7}$ See: D.E. Ewing, Jr., "Film noir: Style and content", [in:] Film Noir Reader 2, eds. A. Silver, J. Ursini, New York 2003, pp. 74-75.

${ }^{8}$ A. Helman, Film gangsterski, Warszawa 1990, p. 68. Unless indicated otherwise, all translations by the author.

${ }^{9}$ Ibid., p. 74. 
aries. The world they depict is dark and awkward but, paradoxically, that effect is achieved through the use of humor and comic strategies such as parody and pastiche (but not only). For example, typical noir films of the classical period, as well as neo-noir films, follow the path of hard-boiled fiction, so that noir detectives are tough guys who rely on their intuition, as opposed to clever and brainy Sherlock Holmes or Hercules Poirot types. The Coens make their detective/policewoman figure first funny, and second, always confused, thus reversing the schema of the investigator's personality in noir film.

The construction of Fargo is based on coniunctio oppositorum. On the one hand, it is an awfully murky story without any hope or solution, showing a pandemonium of absurd that no one can control, while on the other hand it depicts a dreadfully amusing reality filled with paradoxes that make the audience laugh. As a result, "the sad, ugly, and somehow inevitable events that follow, combined with the self-destructive nature of many of the characters and the overall atmosphere of doom, have led many critics to place the film in the tradition of film noir. Yet, in June 2000, the American Film Institute placed Fargo on its list of the 100 greatest American film comedies. How can a film noir be a comedy? Such an opposition is not as contradictory as it might initially seem, and while it points to the Coens' sense of playfulness, it also underscores genuinely distinctive aspects of their work". ${ }^{10}$

Indeed, Fargo is playful. Not many researchers have underlined or appreciated the role of humour in creating noir worlds. Although Foster Hirsch, referring to Double Indemnity (dir. Billy Wilder, 1944), noticed that "mordant humor seeps through even the darkest moments of the action" "11 and James Naremore considers The Maltese Falcon (dir. John Huston, 1941) as "strikingly witty, especially at the level of performance", ${ }^{12}$ contemporary noir films often neglect this aspect of the noir idea, particularly when the films are not parodies or pastiches. But in the Coens' Fargo we find more than just that as they use a sense of humor characteristic for this tendency (playfulness), interspersing elements of slapstick comedy and situational comedy - both conventions rarely connected with noir sensibility.

Thomas Leitch introduces the term "playful" in order to refer to the sense of humor in film noir and underlines that "noir is playful all the way down to the depths of its dark heart. Its playfulness is not a counterpoint to its seriousness. It is even more intrinsic, more essential, than its seriousness. And it leaves its mark everywhere". ${ }^{13}$ Leitch also situates playfulness in the context of playing with viewer expectations. Film noir can be playful through dialogue, narrative structure and its treatment of gender roles. Fargo is playful in all these aspects

10 W.G. Luhr, "Introduction", [in:] The Coen Brothers' Fargo, ed. W.G. Luhr, New York 2004, p. 3.

${ }^{11}$ F. Hirsch, The Dark Side of the Screen: Film Noir, San Diego 1981, p. 5.

12 J. Naremore, op. cit., p. 61.

13 T. Leitch, "Noir at play", Studia Filmoznawcze 31, 2010, p. 85. 
but goes even beyond, and, unlike most noirs, employs black humor, irony or pastiche. Furthermore, playfulness influences all of the main genres weaved into the film's structure. David Sterritt (who considers film noir a separate genre) sums up the Coen brothers' strategy as revisionism, proposing that Fargo is a melting pot of genres, but also suggesting that there is the possibility of labelling the movie a new genre entirely. "Fargo, in his opinion, is less specific and more subtle in its genre parody characteristics than most other Coen films. Nevertheless, even casual spectators will easily spot the movie's roots in the traditions of small-time comedy, Grand Guignol grotesquerie, true crime docu-drama and especially film noir edginess $[\ldots]^{\prime \prime}{ }^{14}$

In order to make Fargo genre identity less complicated and convoluted I propose to follow its structure, with its three main subplots that sometimes cross paths but never quite end up together, and the characters assigned to them. Eddie Robson claims that: "The story of Fargo is divided into three basic areas, with one featuring Jerry, his family and his workplace, another featuring Carl and Gaear and a third featuring Marge [her husband and co-workers - K.Ż.]. These areas rarely cross over and, when they do, this signals a turning point in the plot [as well as provides playfulness - K.Ż.]. Jerry hiring Carl and Gaear starts the plot running; Carl and Gaear then kidnap Jean; Marge tracks Shep down and speaks to Jerry; Shep beats up Carl; Carl meets Wade and kills him; Marge's presence panics Jerry into giving himself away; Marge finds Gaear and catches him. Most of the film's progress can be summarized in those encounters. The rest is character stuff', 15

The three subplots also refer to the three main noir film genres, where each is presented with a twist, and the passage of time clearly reveals noir-based chaos and absurdity. The first subplot is headed by the police officer Marge and her investigation, and alludes to detective stories and crime dramas, even if it can be also unexpectedly read as a family melodrama or maternity drama. Jerry's story can be read as melodrama of mischance, typical noir fiction in the spirit of Cain stories with crime at its core (such as The Postman Always Rings Twice) but the elements of the dark love story with its femme fatale figure are replaced with family drama. The story of Carl and Gaear definitely belongs to gangster cinema, though a touch of horror and slapstick is easily noticeable and clearly influences the character of the plot.

In the following parts of this paper I will trace genre inconsistences and incongruities in relation to the three subplots. Hopefully, I will manage to support Luhr in claiming that "[Film noir - K.Ż.] is a label from which the Coens have repeatedly distanced themselves, and for good reason. They do not want to be

${ }^{14}$ D. Sterritt, "'Fargo' in context: The middle of nowhere?", [in:] The Coen Brothers'..., ed. W.G. Luhr, p. 16.

15 E. Robson, Coen Brothers, London 2013, p. 160. 
seen as simply remakers of old films or as filmmakers entrapped within nostalgia for the past. However, in their very distancing of themselves from the stereotypes of film noir, they may, in fact, place themselves centrally within its tradition". ${ }^{16}$

\section{Marge: Caring mother and patient wife in a cop'suniform}

Noir crime stories, as well as other genres, often begin with an investigation. The detective, either a private eye or a police officer, appears at the crime scene immediately, most often in the opening scene or shortly after. This is not the case in Fargo, where we wait for Marge to enter the snowy world of Minnesota for quite a long time, and when she does appear, we follow her as she potters about her home, performing her morning rituals. As the phone rings early in the morning, we expect the man asleep in the bed to rush out. Instead, he puts on a dressing gown and prepares scrambled eggs for his pregnant wife, who then heads out to face the worse crime she has ever seen in her life.

Marge, in her police uniform and always munching food, is a far cry from Bogart-type private eyes, such as Marlowe (The Big Sleep, dir. Howard Hawks, 1946), or the rogue cops of the 1970s most often epitomized by Harry Callahan (Dirty Harry, dir. Clint Eastwood, 1971) ${ }^{17}$ of the noir and neo-noir traditions. Marge is neither lonely nor a cast away from society, like Holmes or Marlowe. She has a husband and is expecting a child. She has no doubts about the meaning of life, and has a good opinion of the morality of modern societies. Marge trusts people and believes in their honesty and good will. She tries to cooperate with her slow-witted co-worker Lou, with the increasingly desperate and chaotic Jerry, and even at some point she had dated the obviously mentally unstable Mike Yanagita. She is almost never cross, even when faced with bad will. She also lacks anything that would set her aside from others, possessing neither charm nor a standout personality.

We can admire the spoiled, socially alienated and unadjusted, but impressively clear-sighted Holmes, or the ironical but morally doubtful Spade — we laugh along with them as we watch the world revolve. But Marge remains the object of our laughter. Comic tones prevail, particularly in the scene where she detains Gaear. Seeing the dangerous kidnapper and a human leg sticking out of a woodchopper, the policewoman is placid, no disgust or shock register on her face. She operates with her natural, narrow-minded logic and first tries to overcome the noise of the machine with her voice. When she realizes it is impossible, she points

${ }^{16}$ W.G. Luhr, “'Fargo': 'Far removed from the stereotypes of...'”, [in:] The Coen Brothers'..., ed. W.G. Luhr, p. 98.

17 See: E. Durys, Amerykańskie popularne kino policyjne w latach 1970-2000, Łódź 2013, pp. 140-239. 
to her badge to announce her presence and function. Consequently, she neither fits the description of the "eccentric amateur looking for mental exercise", nor the "professional selling his service and favors for money and using violent methods in the name of protecting the law". ${ }^{18}$

Her character also does not reflect the tradition of the armed policewoman from The Silence of the Lambs (dir. Jonathan Demme, 1991) or Copycat (dir. Jon Amiel, 1995) who, according to Elżbieta Durys, relies on her brains and her cleverness to chase criminals, rather than resorting to violence. ${ }^{19} \mathrm{I}$ also believe that Marge's figure to some extent "ironically questions the stereotype of the "rogue cop" as her "kind-heartedness, warmth, empathy and politeness" 20 are something these types do not have. But it is doubtful whether she leads a "boring and calm life by the side of her devoted and loving husband". Norm, Marge's husband, acts like a spoiled child she has to take care of all the time, while he spends his time trying to reassure her he is worth something (for example, when he prepares a painting to be featured on stamps for a competition). Yet, Marge does not "methodically and consequently head towards solving the case", ${ }^{21}$ at least not on her own, and her success has nothing to do with superior professional skills.

Classic detective investigations are based on intellectual cleverness, brilliant deduction and the ability to create associations. Noir private eyes also rely on intuition and a thorough knowledge of human nature. Marge is merely a welltrained, disciplined, ordinary police officer, who lacks imagination but knows procedure and sticks to it (as in the detention scene discussed above). She is a team player, she remains calm when giving lessons to Lou (explaining to him that DLR car plates refer to dealership rather than anything else) and never forgets to praise others (her infallible "Good job!") if they were helpful. Fargo, similarly to docunoir series, ${ }^{22}$ painstakingly depicts the collective efforts of official law enforcement but on the micro-scale, which of course creates a parody in pastiche. Instead of elite government departments, we get a close look at the work of local police officers, standard questionings and sometimes the mistakes that are made. When entering the crime scene, Marge throws up (she is pregnant) and then carelessly treads the snow-covered field at the same time destroying potential evidence. The policemen of Fargo wear regular uniforms (which look funny in their winter iteration) and most often deal with trivial offenses. Police work in Minnesota has nothing to do with the battle between good and evil, it is rather routine assignments

18 P. Włodek, „Świat byt przemoczona pustką”. Czarny kryminat Raymonda Chandlera w literaturze i filmie, Kraków 2015, p. 17.

${ }^{19}$ E. Durys, op. cit., p. 441.

${ }^{20}$ Ibid., p. 442.

${ }^{21}$ Ibid.

22 See: J.P. Telotte, Voices in the Dark: The Narrative Patterns of Film Noir, Urbana 1989; W. Luhr, Film Noir, Chichester 2012; R. Syska, "Dekada cienia: Amerykańskie kino lat czterdziestych", [in:] Historia kina. Kino klasyczne, vol. 2, eds. T. Lubelski, I. Sowińska, R. Syska, Kraków 2011, pp. 474-477. 
that are perfectly suitable for the not-so-brainy Lou and the pregnant Marge. In the face of mounting violence, their experience becomes blatantly insufficient, which introduces a comic dimension and underscores the absurdity of the world.

Marge can also be compared to lieutenant Frank Columbo (Columbo, 19682003). Both are rather unattractive, sometimes absent-minded (Marge lets Jerry escape during her investigation attempts) and very casual in their personality and behavior. Nobody pays attention to them. Marge is admired only by her ex-school friend, who, however, is emotionally unstable. Her husband is not greatly supportive of her success and they never talk about Marge's work or anything related to it. Rayan Doom points out other similarities. In his view, both Marge and Columbo catch criminals by surprise, resorting to polite conversation which disorientates their opponents and leaves them with little room for maneuver. None of them use a gun, and they certainly wouldn't kill. ${ }^{23}$

These similarities are in fact an illusion. Columbo only plays the part of the slow-witted and butterfingered detective. Marge, on the other hand, is at her core straightforward and uncomplicated. She even admits to it herself, in the scene following Gaear's detention: driving calmly, Marge confesses she doesn't understand anything. She doesn't question the explanation, or search for the truth, or wish for things to become rational and intelligible. Instead, she turns to admire another snowy and freezing cold day, a day that does not herald the arrival of spring and better times. Unlike a noir private eye, who would focus on the murky aspects of life, Marge sees the bright side. Additionally, of the things that tend to happen to her in life, none result from careful planning. The Sierra and kidnappers just fall into her lap, as she is driving by. Her lack of reflection on the condition of modern society makes her a police clerk rather than an investigator. Her naïveté, good-nature, and kindly ways are funny (as in the scene where she examines two prostitutes with no sign of irritation but a grin) and terrifying at the same time. Are we really to rely on the likes of her for protection?

Marge's character also does not fit the image of a defender of the law. Noir detectives, whether in their classical incarnation or as contemporary investigators in police dramas can, one way or the other, be given the status of heroes. But the small-town policewoman seeks her fortune and finds fulfillment elsewhere. When not engaging in professional duties, she appears to be in her natural element at home. Most often we see her domesticated by her whining, attention-seeking, self-centered husband. The couple spends most of their time in bed, in front of the TV (and once the investigation is over, bed in front of the TV is where we find them again, with no trace of a reaction to an experience that should make them pause) or walking around the kitchen in nightgowns and slippers. They live out normal, but monotonous middle-class lives, played out against the calm backdrop of home. Above all, patient and compassionate Marge stars in the role of the loving and caring mother.

${ }^{23}$ R. Doom, The Brothers Coen: Unique Characters of Violence, Santa Barbara 2009, pp. 76-77. 
Pamela Grace rightly points out that the scene in which Marge is shown kneeling in front of the body of the dead policeman (the kidnappers' first victim) resembles Michelangelo's Pieta. However, one thing is strikingly absent from this portrait: Marge looks surprised, rather than suffering. It appears there is a schizophrenic split in her existence, but Marge does not seem bothered by it. Her outfits are a telling clue of this contradiction: Marge is shown either wearing casual sleepwear (robes, nightdresses, gowns, etc.) or police uniform, with loose shirts, jackets, trekking shoes and hats with flaps. Regardless of the role she plays, that of wife or police officer, Marge is always on duty. She is never just the woman Marge (the one exception is her strange date with Mike Yanagita).

What can we tell about her expectations and dreams? Hardly anything. Does she have an inner life? It is doubtful. Marge never looks sexy either, not even for a minute. Nor is the spleen of noir detectives her attribute. She is not familiar with the cleverness, wit, and nastiness of Sherlock Holmes. Paradoxically, Marge's corporeality and physiology is why viewers are drawn to her character and curious about her persona. Can a police officer carrying a big pregnant belly, suffering from morning sickness and binge eating (the movie is punctuated by her abundant meals) turn out to be a skillful investigator? Marge's vital functions make her human, but not the character genre aficionados would expect. She lacks the cynicism and detachment, the alienation of the noir private eye. The only feature she has in common with them is addiction. She is enslaved by consumption as much as noir investigators are enslaved by drugs or alcohol. She eats constantly, and her diet of fast food and donuts is unhealthy. Marge abuses these ordinary pleasures and admires life as often as Spade or Hammer reject it; it fills them with disgust.

The genre scheme has been turned upside down as the banality of life enters the existence of the leading detective figure and opens the door to the absurd of noir film. The Coen brothers are playful in this respect. The aura of mystery surrounding noir detectives disappears, the clichés of noir cinema have no place here. Instead of the trench coat flyboy with a glass of whiskey on the rocks in hand, we follow a woman who is mothering the world, addicted to calories and middle-aged, lacking the power to reflect on the human condition. She is involved in family matters more than in the nuances of the investigation, and that is why Marge remains the heroine of a small-town drama rather than of a detective story.

\section{Jerry: Desperate everyman trapped in the American dream}

William Macy's character, Jerry Lundergaard, is the first we meet on screen. In the opening sequence the camera slowly shows him emerging in his car against the snowy and stormy background of the Midwest. There is no other human being in sight, and there isn't even a horizon line to suggest a sense of direction. Jerry 
is alone and isolated in the no man's land that is Minnesota. On the one hand, the framing suggests his condition and his situation, on the other, noir darkness is replaced with the omnipresent white of the blizzard. Yet the sense of emptiness and pessimism remains throughout.

Because the following scene is set in a seedy bar and depicts kidnapping arrangements, the viewer begins to see Lundegaard as a heartless criminal, a greedy and selfish man who tries to live a better life than he deserves. However, the conversation clearly shows this assumption to be wrong. We are not witnesses to a crime drama, instead we are watching a comedy of errors. Jerry can be seen as a typical noir fiction protagonist, an everyman accidentally involved in a criminal affair, like Richard Wanley in The Woman in the Window (dir. Fritz Lang, 1944) and other characters in noir movies. The beginning of the story also echoes the melodrama of mischance genre, best known from James M. Cain's 1934 novel The Postman Always Rings Twice and its movie adaptions in the noir (dir. Tay Garnett, 1946) and neo-noir fashion (dir. Bob Rafelson, 1981).

Yet, only Jerry's ordinariness is doubtless, the other elements do not follow noir plot devices. Lundegaard is a car salesman, not an insurance salesman (like Walter Neff, the ordinary protagonist in Double Indemnity). He orders his wife's kidnapping not because he has fallen in love with someone else and wants to start a new life, and not because of greed. He is a victim not of seduction by a femme fatale, but a victim of his own helplessness and naïveté. Jerry truly believes the kidnapping will be fake and he only put the plan together to get his father-in-law to pay the ransom money which he needs to cover up his mistakes. Lundegaard does not want to hurt his wife, and he orders a masquerade, or at least he thinks he does. Things go wrong from the beginning, as a result not of chance, but of Jerry's own failures.

He may be a liar and a thief, but he is no criminal mastermind. He certainly cannot predict the consequences of his actions, and is incapable of devising a scheme to get himself a bit of money - as Billy Wilder's Neff (Double Indemnity) or Gillis (Sunset Boulevard) did. In fact, Lundegaard is too ordinary to make a decent criminal, and evidently too desperate to retain control of the situation and his own emotions. In many noir films the "detective faces an external evil which threatens his family and forces him to fight back [Suddenly (dir. Lewis Allen, 1954), Cape Fear (dir. J. Lee Thomson, 1962)]. The Coen brothers introduce this pattern too, in a subversive way. Instead of being a protector, Jerry becomes a real danger to his family and the spiritus movens of all the unexpected events. In the end, he causes a real tragedy — not only does Jean die, but his father-inlaw is also killed. Jerry is arrested and his son is essentially orphaned. Earlier on, Lundegaard is also shown as an inept parent who forgets the very existence of his child and does not pay attention to the boy's emotions. Joel Coen explained: "What interested us from the start in the William Macy character was his absolute incapacity, even for one minute, to project himself into the future and evaluate the 
consequences of his decisions. There is something fascinating in that total absence of perspective. He's one of those people who construct a pyramid without thinking for a moment that it could collapse". 24 There is also something terrifying and deeply pessimistic in his mode of functioning.

Jerry's story does not follow the rules of family drama noir, but instead becomes a family drama based on the lack of self-consciousness and a masculinity crisis caused by the American dream and the pressures arising from the cult of individualism. Jerry feels he is a nobody. He works for his father-in-law and depends on him financially. At work, his photo is one of many in a row. The other employees ignore him, clients scream at him. We see no evidence of professional success. On the contrary, somehow Jerry Lundegaard has managed to fall into debt. But the main problem is his father-in-law Wade — a self-made man, owner of a prosperous business with his own accountant by his side. He either ignores Jerry or humiliates him. Depicted as a monster, Jerry's father-in-law is eager to tear him into pieces, to limit his freedom, deceiving and abusing him. After a meeting during which Jerry's idea of buying parking lots is discussed, Jerry is totally devastated, but stays silent — only to get back into his car and jump in frustrated anger. Wade not only controls his son-in-law's professional career but also orders him around in his own home, which he constantly visits, staying for meals without being invited. Anytime he is around, Jerry becomes nervous and stressed, his face changes and erupts in deepset lines. Wade also interferes with Scotty's upbringing, he watches TV on Jerry's couch, with a glass of whiskey in his hand, even telling Jean and Scotty they don't have to worry about their future. But Lundegaard is not a recipient of his "mercy", he is not part of the family at all. When Jean disappears, Wade takes over and decides to deliver the ransom on his own. Jerry has no control over anything and is a pawn in someone else's game. From that perspective Fargo is not only a crime story but also a family drama.

Desperate, sad, and lost, in his down jacket, snow boots and funny hat, with a face covered with worry wrinkles, Lundegaard resembles a teddy bear in need of a hug rather than a scheming and greedy criminal, or even a petty swindler. He always stands in the doorway, and we also see him inside window frames, so he is visually connected with liminal or transitory spaces. Jerry must make a decision, cross the line, choose between the life of a common man with its misery and the possible benefits he could reap from doing wrong. Finally, he takes a step and enters the criminal world. Nonetheless, he is constantly shown amid Minnesota's snowy desert — surrounded by white emptiness, struggling with the wind and snowfalls, a lonely and isolated man, entirely on his own. Even when we see him in enclosed spaces (in his office or in a car), rarely is there someone else there and blinds or windows separate him from the rest of the world.

${ }^{24}$ M. Ciment, H. Niogret, "Closer to the life than the conventions of cinema: Interview with the Coen brothers" [interview held in Cannes on 16 May 1996, reprinted from Postif, September 1996], [in:] The Coen Brothers' ..., ed. W.G. Luhr, p. 114. 
Afraid of life, unable to communicate with people, the poor car salesman is stuck in the absurdity of unpredictable events that he started, but cannot control as he had thought he would. Lundegaard is, in some respect at least, the Buster Keaton protagonist fighting fiercely against forces stronger than him. But, contrary to Keaton's characters, he fails spectacularly as he turns out to be an unimaginative coward, devoid of any moral character. Jerry is also the victim of the myth of the self-made man. His office is filled with awards and trophies that he wishes he had won. Too common and too cowardly, Jerry can never reflect on his situation or his human condition. In the final scene, we see him struggling with police officers, like an angry child, tireless in his absurd efforts.

\section{Carl and Gaear: Unleashing the wild forces of fatalistic reality}

Jerry, a loser and desperado lacking self-confidence, hires a couple of hoodlums to execute his plan, effectively placing his future in their hands. Carl Grimsrud and Gaear Showalter are supposed to bite, as he can only growl and whimper. The pair are violent and cruel, greedy and uncontrollable, ruthless and psychopathic. But are they like the criminals of gangster movies and thrillers? Their twisted personalities do not echo those of classic noir films maniacs and crooks such as James Cagney's characters in White Heat (dir. Raul Walsh, 1949) or Kiss Tomorrow Goodbye (dir. Gordon Douglas, 1950). In American post-war noir thrillers abusive violence became a part of a character's mental issues. However, "psychologizing" most often accompanied a romantic rebel overtone. No similar explanations are offered for the behavior of Carl and Gaear.

Jerry's henchmen are idiots who are mean and bad right through and through. They resemble horror monsters, creatures out of this world. With no past and no memories, they are more like animals, no motivation for their acts can be subsumed, no roots of depravity found in their social or personal background. It seems they were shaped by nature, or basic instincts rather than the figure of a domineering mother. They appear in the Midwest out of the blue, like a deus ex machina. In the first scene, we find them sitting in the crossroads bar, an isolated place, surrounded by snowy fields. The perfect horror scenery, this is the place where a grim chain of events unfolds. Further on in the movie Carl and Gaear only raise commotion, bringing destruction and chaos. They become the personification of Lundegaard's frustration and despair, but these perverted creatures also prove that modern, wealthy society (personalized by Wade too) lacks the moral fiber to stand up against them. Additionally, "they represent a chaotic modern America penetrating small town purity and bringing hell with them. They're unlucky, urban, two-bit common criminals set loose in Brainerd, embodying the noir 
city unleashed in Middle America. They create an invasion of tension and horror into a way of life they don't understand". ${ }^{25}$

This pair of primitive mobsters brings to mind the image of Paul Bunyan and Bebe Blue Ox. But while Bunyan and Ox, the legendary, probably non-existing figures were there to protect the town and its citizens, Carl and Gaear arrive to destroy the peace. Their interaction and bizarre relationship resembles, at least to some extent, Hardy and Laurel's slapstick characters' mode of functioning. Indeed, inflation is a strategy used towards the genre. Carl and Gaear are grotesque versions of the comic couple that also drives many buddy films. They constitute a kind of dysfunctional family rather than a pair of friends that can be markedly different but respectful of each other's differences. As Doom suggests, the inability to communicate (Carl blames Gaear for his silence during the journey, while Gaear can't stand Carl's constant chattering) is a reflection of Jerry and his wife's relationship. ${ }^{26}$ But in my opinion, Jerry mirrors the overemotional Carl, while Gaear resembles Jerry's authoritative and gloomy father-in-law Wade. Like Jerry, Carl surrenders leadership to Gaear. If you remember, Jerry allows Wade to deliver the money, thereby relinquishing control of events. Just as Grimsrud does not trust him, Wade does not trust Jerry. It is Showalter who does not know how to get rid of the police officer when they get pulled over. Also, as in many buddy movies, Fargo features male comradeship that relegates male-female relationships to a subordinate position (Carl and Gaeare only have sex with prostitutes) but ends up in a surprising, unexpected twist. The unfolding of events does not culminate in a strengthening of ties, a forging of a more solid friendship. Their relationship brings about slaughter, and the escalation of cruelty instead of trust and respect.

Gaear looks like a gigantic lumberjack, and "aptly" murders his accomplice with an axe attributed to Bunyan. The monstrous Grimsrud (notice the "grim" in his name pointing to the ambiance of horror stories) is probably the darkest character of the movie. Gaear says little but when he does, it is to demand in categorical and indisputable terms. He is a chain smoker (one of the prostitutes describes him as Marlboro Man) silently staring into space or at the TV screen, he lives a passive life, craving only food. Is he mentally retarded or suffering existential dilemmas as Jerold Abrams suggests? ${ }^{27}$ Is he constantly engrossed in meditation, pensive, filled with pain and melancholy, a loner, or simply an autistic type, suffering from compulsive behavior? What is certain is that these are indicators of the character's radical alienation. Violence seems to be a coherent part of his nonhuman nature, the only power that he obeys. Grimsrud does not hesitate, he kills without thinking about possible consequences, he is ruthless and unstoppa-

25 R. Doom, op. cit., p. 79.

${ }^{26}$ Ibid.

27 J.J. Abrams, “'A homespun murder story': Film noir and the problem of modernity in 'Fargo"', [in:] The Philosophy of the Coen Brothers, ed. M.T. Conard, Lexington 2009, p. 219. 
ble, which makes him more dangerous than a psychotic gangster: his kind of evil is a satanic horror movies kind of evil.

In buddy films, characters always differ because opposites attract. Consequently, Carl is lively and garrulous. His body is permanently tormented by spastic reflexes and his face is distorted by bizarre grimaces. Like many comic characters, he is "funny looking" (the prostitute's words) and struggles with objects or circumstances of nature (sometimes with both, for example, as he is attempts to hide the black suitcase with the money in the snowdrift). Showalter (note the "show" in his name referring to this character's compulsive need for attention, he is also constantly showing off like many slapstic comedians) is constantly on the run, getting things done, arranging finances and setting up accounts - he is in charge of all the practicalities of the deal. He does persist in his efforts to control the situation, even after he is shot in the face, which makes his performance even more hilarious.

There are more similarities between Carl and Jerry that merely underscore the indolence they stand for. Jerry is a master of hypocrisy, and even though his is a minor kind of evil, he still is nasty - like a gremlin. Both are dishonest and unscrupulous liars who double-cross their partners. Showalter attempts to hide some money from Gaear and to keep the car, not admitting how much he really got. Jerry steals the Sierra from his father-in-law's company and also takes more than what is needed to secure Jean's release. Naturally, of course, Showalter is more advanced in his depravity. In fact, he epitomizes what Jerry might turn into. Wade at the same time is almost equally gloomy, domineering, and apathetic as Gaear. But while the latter kills and invites contempt, the former merely remains a highly repulsive figure. Yet despite their failings, Jerry and Wade retain a veneer of normalcy, something which has long disappeared from the worlds of Carl and Gaear. Although buddy films rely on personality collisions, Fargo makes all their male protagonists alike in the way they deal with the crisis of masculinity, ignoring moral values and human virtues, losing control and sliding into madness.

\section{Conclusions}

At first glance, the Coen brothers' Fargo seems far removed from the noir tradition when compared with genre conventions. Paradoxically, however, even when the brothers make use of elements of detective stories, crime drama, gangster films and refer to well-known noir plot devices, they do so in highly unconventional and subversive ways, simultaneously bending, blurring, and blending the core elements of film genres seemingly removed from the noir convention, such as slapstick comedy, maternity drama, buddy film or horror. Fargo is made up of distinct film genres, all of which have been reconstructed, at least to some 
extent. As a result, the movie is playful at heart and an outstanding noir comedy. Fargo retains a sense of darkness, pessimism, chaos, nihilism and lack of hope for a better future - elements of the noir sensibility. What is more, the feelings of morbidity and absurdity are evoked with greater intensity than in many classical noir films. The story of a hopeless, confused but success-driven small-town everyman, chased by a smug, self-satisfied police detective living an inauthentic middle-class existence, facing evil in the characters of two hilarious petty criminals from hell proves that human values are long forgotten and that the modern world, even in idyllic small-town America is soaked with the absurd and with cruelty. But Fargo also proves that, as Geoff King correctly notes, in their development "genres undergo various cycles rather than any linear process of evolution" and there is nothing like an "automatic or in-built dynamic" that marks their transformation. $^{28}$

\section{Bibliography}

\section{Secondary sources}

Abrams J.J., "'A homespun murder story': Film noir and the problem of modernity in 'Fargo"”, [in:] The Philosophy of the Coen Brothers, ed. M.T. Conard, University Press of Kentucky, Lexington 2009, pp. 211-223.

Doom R.P., The Brothers Coen: Unique Characters of Violence, ABC Clio, Santa Barbara 2009.

Durys E., Amerykańskie kino policyjne w latach 1970-2000, Wydawnictwo UŁ i PWSFTviT, Łódź 2013.

Ewing Jr. D.E., "Film noir: Style and content", [in:] Film Noir Reader 2, eds. A. Silver, J. Ursini, Limelight, New York 2003, pp. 73-97.

Helman A., Film gangsterski, Wydawnictwo Artystyczne i Filmowe, Warszawa 1990.

Hirsch F., The Dark Side of the Screen: Film Noir, Da Capo Press, San Diego 1981.

Kempna-Pieniążek M., Neo-noir. Ciemne zwierciadło czasów kryzysu, Wydawnictwo Uniwersytetu Śląskiego, Katowice 2015.

King G., New Hollywood Cinema: An Introduction, Columbia University Press, New York 2002.

Kerr P., "Out of what past? Notes on the B film noir", [in:] Film Noir Reader, eds. A. Silver, J. Ursini, Limelight, New York 2000, pp. 107-127.

Leitch T., "Noir at play", Studia Filmoznawcze 31, 2010, pp. 83-94.

Luhr W.G., Film Noir, Wiley-Blackwell, Chichester 2012.

Luhr W.G., ed., The Coen Brother's Fargo, Cambridge University Press, New York 2004.

Naremore J., More Than Night: Film Noir in its Contexts, University of California Press, Berkeley 2008.

Robson E., Coen Brothers, Virgin Books, London 2013.

Syska R., "Dekada cienia: amerykańskie kino lat czterdziestych", [in:] Historia kina. Kino klasyczne, vol. 2, eds. T. Lubelski, I. Sowińska, R. Syska, Universitas, Kraków 2011, pp. 409-479.

Telotte J.P., Voices in the Dark: The Narrative Patterns of Film Noir, University of Illinois Press, Urbana 1989.

${ }^{28}$ G. King, op. cit., p. 131.

Literatura i Kultura Popularna 24, 2018

(C) for this edition by CNS 
Włodek P. (2015), ,Świat byt przemoczona pustka”. Czarny kryminat Raymonda Chandlera w literaturze i filmie, Wydawnictwo Naukowe Uniwersytetu Pedagogicznego, Kraków 2015.

Żyto K., Film noir i kino braci Coen, Wydawnictwo UŁ i PWSFTviT, Łódź 2017.

\section{Filmography}

Big Sleep, The, dir. H. Hawks, USA 1946.

Cape Fear, dir. J.L. Thomson, USA 1962.

Copycat, dir. J. Amiel, USA 1995.

Dirty Harry, dir. D. Siegel, USA 1971.

Double Indemnity, dir. B. Wilder, USA 1944.

Fargo, dir. J. Coen, USA 1996.

Killers, The, dir. R. Siodmak, USA 1946.

Kiss Tomorrow Goodbye, dir. G. Douglas, USA 1950.

Maltese Falcon, The, dir. J. Huston, USA 1941.

Postman Always Rings Twice, The, dir. B. Rafelson, USA 1981.

Postman Always Rings Twice, The, dir. T. Garnett, USA 1946.

Silence of the Lambs, The, dir. J. Demme, USA 1991.

Suddenly, dir. L. Allen, USA 1954.

Sunset Boulevard, dir. B. Wilder, USA 1950.

White Heat, dir. R. Walsh, USA 1949.

Woman in the Window, The, dir. F. Lang, USA 1944.

\section{TV Series}

Columbo, executive producer: P. Saltzman, USA 1971-1978, 1989-1998, 1998-2002, 2002-2003.

\section{Detours of absurdity: Coen brothers' Fargo in the noir melting pot of genre patterns}

Summary

The idea of film noir, especially neo-noir, viewed as a stable and clear genre has as many supporters as detractors. The controversy is nothing new, and a compromise is still elusive. The reason for such an impasse is not merely the intransigent stance of opponents, the strength of their arguments, but is also a result of the hybridization of genres in main stream cinema (and elsewhere). I discuss the problem presented by film noir in the context of the question of generic identity on the example of the Coen brothers' Oscar-winning Fargo. The movie is an interesting case study as it does not make use of any of the genres typical for film noir in its unadulterated form (i.e. genres associated with film noir in its classical era). In Fargo, Joel and Ethan Coen skillfully combine elements of the detective story (though not necessarily associated with hard-boiled fiction) with crime shows, gangster movie with thrillers about psychopaths, comedy with tragedy and family drama with melodrama of mischance. The result remains the same - the world of Fargo stays noir, dark and pessimistic and permeated with the absurd. 